\title{
Communicative Reading Comprehension Competency Influences Written Composition Skills Performance of Faculty in English Discipline
}

\author{
Ma. Delia G. Ambulong ${ }^{1}$, Jazziem M. Jumsali ${ }^{1}$, Annie Vee M. Barnido ${ }^{1}$, \& Allan J. Abdurahman ${ }^{1}$ \\ ${ }^{1}$ Tawi-Tawi Regional Agricultural College, Bongao, Tawi-Tawi, Philippines \\ Correspondence: Ma. Dellia Ambulong, Tawi-Tawi Regional Agricultural College, Bongao, Tawi-Tawi, Philippines.
}

Received: August 12, 2021

doi:10.5430/wjel.v11n2p177
Accepted: September 24, $2021 \quad$ Online Published: September 26, 2021

URL: https://doi.org/10.5430/wjel.v11n2p177

\begin{abstract}
James Britton proposed three primary language functions, which researchers tested using faculty members from Tawi-Tawi Regional Agricultural College (TRAC), for communicative reading comprehension-transactional, expressive, and poetic. Tawi-Tawi has many schools with high literacy levels, which contributes to a better society and a more peaceful country. The results revealed that the gender of the respondents had no bearing on their level of communication competency, and no significant differences were found between male and female faculty members. Additionally, there was no significant relationship found between the socio-demographic profiles and teaching performance of the faculty members in the English discipline.
\end{abstract}

Keywords: communication competency, communicative reading comprehension, Tawi-Tawi Regional Agricultural College, Philippines

\section{Introduction}

Faculty members' performance in reading comprehension and written composition skills in English as a second language (ESL) at Tawi-Tawi Regional Agricultural College's BSAgEd department was used as a definite purpose of communication discourse. Students in high school are thought to have poor English skills. This can be attributed to a lack of instructional facilities and training seminars for students, which help them to improve their proficiency in academic and vocational disciplines. It is necessary to determine the reading comprehension and writing skills of first-year students in English composition. In the preceding empiricism, it was deemed necessary for teachers to provide the essential activities for students to improve their communicative competence in all fictions of language.

This means that students will become more aware of their audience (readers) and the context in which they are speaking. Students become empowered to achieve passing goals as their awareness grows, and they learn how to use the teaching-learning register appropriately.

\subsection{Objectives}

The primary goal of this research is to determine the freshmen's performance levels of reading comprehension and written communicative skills using the reading and writing theory of composition (Personske, 1987). This research specifically addresses the following five questions:

1. What is the level of reading comprehension competence among TRAC freshmen of Agricultural Education in the English discipline?

2. What is the performance level of freshmen of Agricultural Education in the English discipline at TRAC regarding academic written composition skills?

3. Is there a significant difference in performance between reading comprehension competence and academic written composition skills of freshmen of Agricultural Education in the English discipline at TRAC?

4. Is there a relationship between reading comprehension and academic written composition skills among freshmen in Agricultural Education in the English discipline at TRAC?

5. What effect does reading comprehension have on academic written composition skills among freshmen of Agricultural Education in the English discipline at TRAC? 


\subsection{Literature Review}

Language, culture stresses, and a language theoretical framework that protects the speakers' views of reality play essential roles in the development of language competencies. Language is rarely used for just one function at a time, but rather for two or more functions, such as speaking and writing (Ahamad, 2002; Barman, 2020; Demirel \& İşisağ, 2019; Ge, 2021). Individuals' abilities to express their intentions through the structure of language will gradually improve as they grow older.

A teacher using the functional approach can create a setting for ESL students that will engage them directly in mature, individualized reading and writing tasks. Language composition is learned with the aim of socializing and controlling the behavior of others (pragmatically quested by Brunner, 1970). A speech act is an "interpersonal", verbally encoded, social gesture made by one person to another. It is the interpersonal function of language (Garvey, 1977). Language acquisition is a socialization process for which an individual needs a framework to decode and encode language form and context through social interaction. As a social, educational, or even technological tool, language has evolved to share ideas with others, allowing for complete interaction. Brown, Levinson, \& Levinson (1987); Brown \& Campione (1994); Kouiri, Agouram, \& Kadouri (2021); Rahman, Sony, Hossen Rubel, Alam, \& Liza (2020); Yunus, Umiera, Makhtar, Norman, \& Hashim (2020); and Ababneh (2020) describe initial language learning as a cognitive socialization process.

\subsection{Conceptual Framework}

Researchers used the reading passage model to conduct a composition evaluation examination on a sample of respondents taking periodic (mid-term and final) assessments to determine the progression of reading comprehension skills and written composition skills. The data (scores on a scale rating performance test) was statistically treated using descriptive correlational and inferential statistics. Halliday's sociological theory of English as a second language was also used in the research.

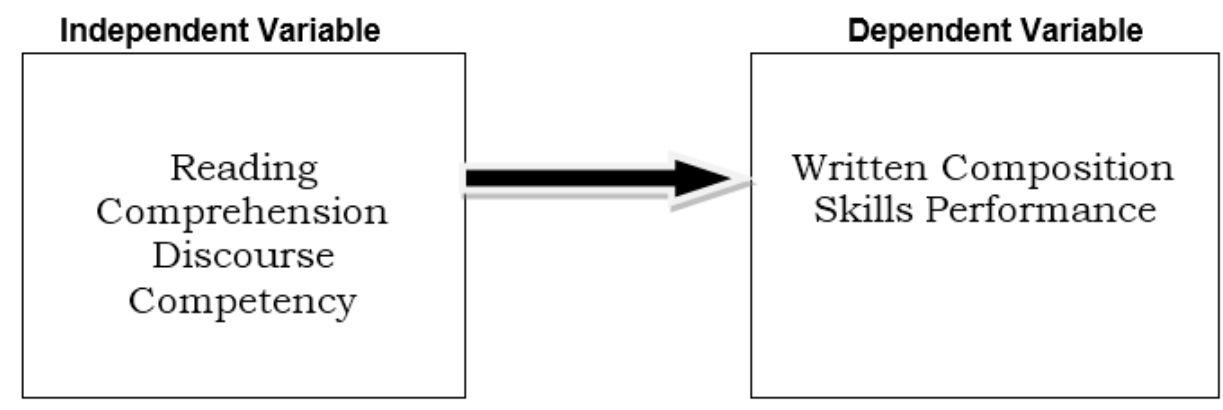

Figure 1. A schematic diagram showing the significant influence of reading comprehension discourse competency on written composition skills among BSAgEd freshmen at Tawi-Tawi Regional Agricultural College

\section{Methodology}

\subsection{Research Design}

This study aimed to describe the teachers' communicative competency and teaching performance at Tawi-Tawi Regional Agricultural College using descriptive correlational research. The researchers used fifty respondents selected using a simple random sampling design to obtain the desired number of respondents from the total population of the school. The data were statistically treated based on the teachers' competency and academic teaching performance measured by the Baluma 5-point scale. This was created to demonstrate which of the teachers performed better in Britton's three language functions.

\subsection{Research Locale}

The study took place at Tawi-Tawi Regional Agricultural College, with respondents drawn from various departments. A total of 30 teachers from the same institution were asked to teach the sampled respondents using Britton's three primary language functions (transactional, expressive, and poetic) (Britton, 1970) in Personske's model of language communicative functions in a classroom setting.

\subsection{Population and Sampling Design}

This study's respondents were all faculty members at Tawi-Tawi Regional Agricultural College who taught English as a subject. This was designed to test communicative discourse competency on a 5-point Baluma scale. The 


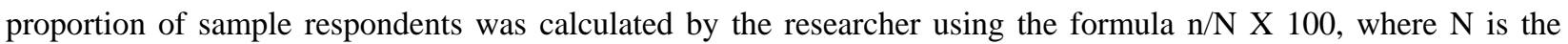
sample size, $\mathrm{N}$ is the population size, and 100 is the constant. The sample size was 50, with 24 males and 26 females, based on the calculation using $45 \%$ of the population.

\subsection{Research Instruments}

This study used the following instruments to process the study's data. The respondents' communicative competence and teaching performance in English as a second language were monitored using Gay Su Pinnel's observation, exemplifying the three major classroom discourses (cited in Norton, 1993).

A closed-ended questionnaire was used to collect data to create a descriptive socioeconomic educational profile, which was then compared to the qualitative model of Baluma's 5-point scale rating. It also used Britton's language functions to assess teachers' teaching performance in English as a second language as a medium (Bachman, 1992).

To ensure that each respondent had read and written the comprehension based on the passage framed with Britton's theory in Personske (1987), the researchers used a tabulated summary to record and monitor individual respondents' performances.

\subsection{Validity and Reliability}

The data gathered was assessed by the most capable, well-informed, and knowledgeable panel of experts to determine the instrument's validity. As a result, for a well-polished instrument, their suggestions and comments were vital considerations.

The validated questionnaire was pre-administered to non-respondents-faculty members and teachers in this study - to ensure the instrument's precision and reliability.

\subsection{Data Gathering Procedure}

After the instrument was fully prepared for administration to the respondents, the researchers obtained written permission from the Department of Education's Schools Division Superintendent. The questionnaire was then administered with the consent of the head of department. Three days after distribution, the questionnaires were retrieved.

\subsection{Data Analysis}

The demographic profile of the respondents and significant differences in communicative reading comprehension discourse competency and written composition skills was determined using descriptive research parameters. The relationships between the variables and the respondent-teachers at Tawi-Tawi Regional Agricultural College were also examined. The researchers used frequency count and percentage distribution, and mean and standard deviations to determine the levels of respondents' communicative competency and written composition skills.

\section{Results and Discussion}

What is the level of communicative reading comprehension discourse competency on Britton's three major communicative language functions among faculty members/teachers at Tawi-Tawi Regional Agricultural College?

In terms of expressive function, transactional function, and poetic function, Table 1 shows the level of competency of the TRAC faculty members for each of the three language functions.

Table 1. Levels of faculty members'/teachers' communicative reading comprehension for Britton's three main language functions at Tawi-Tawi Regional Agricultural College

\begin{tabular}{l|l|l|l}
\hline $\begin{array}{l}\text { Factors/Language } \\
\text { Functions }\end{array}$ & Mean & S.D. & Verbal Description \\
\hline Expressive function & 82.82 & 4.284 & Very good competence \\
\hline Transactional function & 80.66 & 4.373 & Very good competence \\
\hline Poetic function & 78.98 & 5.868 & Moderate/good competence \\
\hline Grand mean & 80.82 & 4.284 & Very good competence \\
\hline Scale range of mean & $90-100$ & Verbal description \\
\hline 5 & $80-89$ & Very high competence \\
\hline 4 & $70-79$ & High/very good competence \\
\hline 3 & $47-69$ & Moderate/good competence \\
\hline 2 & 46 and below & Low competence \\
\hline 1 & & Very low competence \\
\hline
\end{tabular}


As shown in the table, TRAC faculty members' communicative competencies in terms of expressive function were rated with a mean of 82.82 percent and a standard deviation of 4.284 , indicating very good competence. Similarly, very good competence was found in terms of transactional function, with a mean rating of 80.66 and a standard deviation of 4.373. However, the respondents gave a mean rating of 78.98, with a standard deviation of 5.868, indicating moderate or good competency in poetic function. However, TRAC faculty members' level of communicative competence in the three major language functions was described as very good, with a mean of 80.82 and a standard deviation of 4.224 .

With mean values and standard deviations in the three language functions (82.82 and 4.284 for expressive function, 80.66 and 4.373 for transactional function, and 78.98 and 5.868 for poetic function), the set of values was revealed to be homogenous. It can therefore be assumed that the respondents' performance ratings were very similar.

What is the level of written composition skills among faculty members in terms of academic capability in English disciplines at Tawi-Tawi Regional Agricultural College?

Table 2. Level of written composition skills among faculty members in terms of academic capability in English disciplines at Tawi-Tawi Regional Agricultural College

\begin{tabular}{l|l|l|l|l}
\hline No. & Statements & Weighted Mean & S.D. & Verbal Description \\
\hline 1. & Subject-Verb agreement & 2.58 & 0.609 & Adequate \\
\hline 2. & Writing Ability & 2.56 & 0.577 & Adequate \\
\hline 3. & Organizational Structuring & 2.52 & 0.544 & Adequate \\
\hline 4. & Conversational Capability & 2.46 & 0.579 & Moderately Adequate \\
\hline 5. & Sentence Analysis & 2.46 & 0.543 & Moderately Adequate \\
\hline 6. & Command in English & 2.42 & 0.538 & Moderately Adequate \\
\hline 7. & Spelling & 2.42 & 0.575 & Moderately Adequate \\
\hline 8. & Grammar & 2.36 & 0.485 & Moderately Adequate \\
\hline 9. & Punctuation & 2.36 & 0.525 & Moderately Adequate \\
\hline 10. & Oral Speech Capability & 2.34 & 0.519 & Moderately Adequate \\
\hline 11. & Theoretical Application & 2.34 & 0.593 & Moderately Adequate \\
\hline 12. & Verbal Analysis & 2.26 & 0.487 & Moderately Adequate \\
\hline 13. & Textual Analysis & 2.22 & 0.465 & Moderately Adequate \\
\hline 14. & Synthesis Analysis & 2.16 & 0.510 & Moderately Adequate \\
\hline 15. & Contextual Analysis & 2.12 & 0.480 & Moderately Adequate
\end{tabular}

\begin{tabular}{lll}
\hline Average Weighted Mean 2.377 & 0.368 Moderately Adequate
\end{tabular}

$2.5-3.0=$ Adequate, $1.5-2.49=$ Moderately Adequate, $1.0-1.49=$ Inadequate

Table 2 shows that twelve of the fifteen statements regarding TRAC faculty members' written composition skills in English disciplines were rated as moderately adequate, while three were rated as adequate.

This study gave the highest weighted mean (2.58) to knowledge in subject-verb agreement with a verbal description of adequate. This implies that the faculty members are well-versed in the subject-verb agreement concept. Following that, with a mean value of 2.56 , is writing ability. Furthermore, the faculty members showed adequate (2.52) organizational structuring knowledge. From this, we can assume that teachers are very knowledgeable about writing organization and paragraph arrangement.

On the other hand, TRAC faculty members scored moderately adequate (2.46) for both conversational ability and sentence analysis. The faculty members' command of the English language and spelling was also moderately adequate (2.42). We can therefore assume that the faculty members are not avid readers of books written in English.

Furthermore, performance in the contextual analysis received the lowest mean value for written composition skills, with a mean rating of 2.12, describing it as moderately adequate. The next lowest performance was for synthesis analysis, which had a mean value of 2.16 and was also moderately adequate.

Written composition skills was rated moderately adequate with an average weighted mean of 2.377 . This implies that the faculty members do not have a strong command of the English language or are not fluent in the language. This may limit their ability to improve the effectiveness and interest of the teaching-learning process for students.

Standard deviation measures as a percentage of the mean values can be used to show the variation of responses on the statements for the participants' written composition skills. As shown in Table 2, all statements had low standard deviation values compared to the mean values, which suggests that the respondents' perceptions of the statements of 
written composition skills performance ratings were similar. The researchers can assume that the faculty members assessed their written composition skills in the English language in terms of the given variables in a similar way.

Is there a significant perceptual difference in the communicative reading comprehension competency and written composition skills between the male and female faculty members at Tawi-Tawi Regional Agricultural College?

Table 3. Significant differences in the communicative reading comprehension discourse competency in Britton's three major language functions and written composition skills between the male and female faculty members at Tawi-Tawi Regional Agricultural College

\begin{tabular}{|c|c|c|c|c|c|}
\hline \multirow{3}{*}{ Variable } & \multicolumn{2}{|c|}{ Mean Ranks of } & \multirow{3}{*}{ T-obs. } & \multirow{3}{*}{ P-value } & \multirow{3}{*}{$\begin{array}{l}\text { Decision on } \\
\text { H0 }\end{array}$} \\
\hline & \multicolumn{2}{|c|}{ Gender } & & & \\
\hline & Male & Female & & & \\
\hline \multicolumn{6}{|c|}{$\begin{array}{l}\text { Communicative reading comprehension discourse } \\
\text { competency }\end{array}$} \\
\hline Expressive function & 82.42 & 83.19 & $-0.64^{(n s)}$ & 0.5223 & Accepted \\
\hline Transactional function & 80.83 & 80.50 & $0.27^{(n s)}$ & 0.7908 & Accepted \\
\hline Poetic function & 79.38 & 78.62 & $0.45^{(n s)}$ & 0.6521 & Accepted \\
\hline Written composition skills performance & 2.408 & 2.349 & $0.56^{(n s)}$ & 0.5760 & Accepted \\
\hline
\end{tabular}

$n s=$ not significant at the $5 \%$ level of significance.

Table 3 depicts the significant perceptual differences in terms of academic capability between the communicative reading comprehension discourse competency and Britton's three primary language functions (transactional, expressive, and poetic) as well as written composition skills of both male and female faculty members who teach English at Tawi-Tawi Regional Agricultural College. Table 3 also shows the results of the t-test for independence/uncorrelated levels of communicative reading comprehension competency and written composition skills.

The findings revealed no significant differences between male and female respondents in communicative reading comprehension competency and written composition skills. The expressive function has a t-value of -0.64 , the transactional function has a $t$-value of 0.27 , the poetic function has a t-value of 0.45 , and the performance of written composition has a t-value of 0.56 with a probability of occurrence greater than the alpha level of significance, which indicates non-significance.

Because the variables tested in the study revealed no significant differences between male and female faculty members, the null hypothesis was accepted. Furthermore, the observed mean ratings support the findings that the respondents' performance for each of the tested variables did not differ significantly. The results also revealed that the respondents' gender has no bearing on their communicative reading comprehension competency in terms of Britton's three primary language functions or on written composition skills in terms of the medium of the English language.

Is there any significant relationship between communicative reading comprehension discourse competencies in Britton's three major communicative language functions and written composition skills in terms of academic capability in the English discipline among faculty members in Tawi-Tawi Regional Agricultural College? 
Table 4. The relationship between the communicative reading comprehension discourse competencies in Britton's three major communicative language functions and written composition skills in terms of academic capability in the English discipline among faculty members at Tawi-Tawi Regional Agricultural College

\begin{tabular}{|c|c|c|c|c|}
\hline \multirow{2}{*}{$\begin{array}{l}\text { Predictor } \\
\text { Variable }\end{array}$} & \multirow{2}{*}{$\begin{array}{l}\text { Regression } \\
\text { Coefficient }\end{array}$} & \multirow{2}{*}{$\begin{array}{l}\text { STD } \\
\text { Error }\end{array}$} & \multicolumn{2}{|l|}{ Students } \\
\hline & & & T-value & P-value \\
\hline Expressive Function & 0.16175 & 0.087932 & $1.84^{\mathrm{ns}}$ & 0.9958 \\
\hline Transactional Function & 0.18487 & 0.084376 & $2.19 *$ & 0.8841 \\
\hline Poetic Function & 0.22811 & 0.086149 & $2.65 *$ & 0.6018 \\
\hline $\begin{array}{l}R=0.64 \\
R^{2}=0.4108\end{array}$ & & & & \\
\hline
\end{tabular}

Table 4 shows that the coefficient $\mathrm{R}(0.64)$ indicates that there was a moderate relationship between communicative reading comprehension discourse competencies in terms of Britton's three primary communicative language functions and written composition skills in terms of academic capability. Furthermore, the coefficient of determination $\left(\mathrm{R}^{2}=0.4108\right)$ revealed that communicative reading comprehension discourse competencies in the three major communicative functions account for 41.08 percent of the variance in written composition skills among the respondents. It also means that this study did not cover 58.92 percent of the factors that contributed to the respondents' teaching performances in terms of academic capability in the English discipline. The F-value of 10.69, with a probability value less than the alpha level ( $\mathrm{p}$-value $=0.0000 .01$ ), indicates that there is a link between TRAC faculty members' communicative reading comprehension competencies in terms of expressive, transactional, and poetic functions, and their written composition skills in terms of academic capability in English.

Similarly, respondents' communicative reading comprehension competencies in Britton's three major communicative language functions showed a directly proportional relationship with their teaching performance in written composition skills in terms of academic capability in English when taken individually. It means that as respondents' reading comprehension communicative competencies improve, their teaching performance in written English composition skills will improve as well, and vice versa. As a result, the former communicative competencies of respondents in the expressive function had a regression coefficient of 0.16175 with a standard error of 0.087932 , despite its $t$-value of 1.84 with a probability value greater than the alpha level ( $p$-value $=0.023>0.05$ ), indicating the existence of a relationship between the communicative reading discourse competency in the expressive function and their teaching. This finding contradicts the previous conclusion that the level of communicative competence of TRAC's faculty members in the expressive function was very good (Table 1). It is possible that the faculty members did not use their expressiveness effectively as a communicative tool in the classroom. Respondents' communicative competencies in the transactional function had a regression coefficient of 0.18487 with a standard error of 0.084376 and a $t$-value of 2.19 with a probability value less than the alpha level (p-value $=0.04750 .05)$, and the poetic function had a regression coefficient of 0.22811 with a standard error of 0.086149 and a T-value of 2.65 with a probability value less than the alpha level $(\mathrm{p}$-value $=0.04750)$

The researchers rejected the null hypothesis at the 5\% level of significance based on the initial findings. There is sufficient evidence to conclude that respondents' communicative reading competencies and their written composition skills (discourse) in the English discipline have a significant linear relationship. The findings also revealed that the first variables (reading comprehension of TRAC faculty members in terms of transactional and poetic functions) are good predictors of written composition skills, but not in terms of expressive function.

Is there a significant relationship between socio-demographic profile and written composition discourse performance of faculty members/teachers in terms of academic capability in the English discipline at Tawi-Tawi Regional Agricultural College? 
Table 5. The extent of the relationship between the socio-demographic profiles and the written composition skills in terms of academic capability in the English discipline among TRAC faculty members at Tawi-Tawi Regional Agricultural College

\begin{tabular}{|c|c|c|c|c|c|}
\hline No. & $\begin{array}{l}\text { Predictor } \\
\text { Variable }\end{array}$ & $\begin{array}{l}\text { Regression } \\
\text { Coefficient }\end{array}$ & $\begin{array}{l}\text { STD } \\
\text { Error }\end{array}$ & Students & \\
\hline & & & & T-value & P-value \\
\hline 1 & Age & 0.0000512 & 0.09614 & $0.01^{\mathrm{ns}}$ & 0.9958 \\
\hline 2. & Sex & -0.017332 & 0.11806 & $-0.15^{\mathrm{ns}}$ & 0.8841 \\
\hline 3. & Civil status & -0.070313 & 0.13363 & $-0.53^{\text {ns }}$ & 0.6018 \\
\hline 4. & Basic monthly salary & -0.018043 & 0.04448 & $-0.41^{\text {ns }}$ & 0.6871 \\
\hline 5. & Degree earned & 0.0057851 & 0.02777 & $0.21^{\mathrm{ns}}$ & 0.8361 \\
\hline 6. & Field of specialization & 0.017347 & 0.02905 & $0.60^{\mathrm{ns}}$ & 0.5539 \\
\hline 7. & Subject handled most & -0.080111 & 0.04195 & $-1.91^{\mathrm{ns}}$ & 0.0637 \\
\hline 8. & Relevance of teaching assignment & 0.065328 & 0.17738 & $0.37^{\mathrm{ns}}$ & 0.7147 \\
\hline 9. & $\begin{array}{l}\text { Number of years of handling } \\
\text { subject }\end{array}$ & 0.04074 & 0.14127 & $0.29^{\mathrm{ns}}$ & 0.7746 \\
\hline 10. & Working experience & -0.077079 & 0.1707 & $-0.45^{\mathrm{ns}}$ & 0.6542 \\
\hline 11. & In-service training & 0.13386 & 0.078674 & $1.70^{\mathrm{ns}}$ & 0.0970 \\
\hline $\begin{array}{l}R=0.42 \\
R^{2}=0.1754\end{array}$ & \multicolumn{5}{|c|}{$\begin{array}{l}\text { F-obs }=0.7350^{\text {ns }} \\
\quad P \text {-value }=0.6987\end{array}$} \\
\hline
\end{tabular}

Table 5 shows that the coefficient $\mathrm{R}(0.42)$ indicates that there was a moderate relationship between the socio-demographic profiles of TRAC faculty members, such as age, sex, civil status, basic monthly salary, degree earned, the field of specialization/concentration, subjects handled the most, the relevance of teaching assignments to the field of specialization, and number of years teaching. According to the coefficient of determination $\left(\mathrm{R}^{2}=0.1754\right)$, the socio-demographic profiles of TRAC faculty members explained 17.54 percent of the variance in teaching performance in the English discipline. It also means that 82.46 percent of the factors that influenced the respondents' written composition and performance were not considered in this study. Although the observed F-value of 0.735 with a probability value of 0.6987 greater than the alpha level $(\mathrm{p}$-value $=0.6987>0.05)$ indicates that there is no significant relationship between the respondents' socio-demographic profiles and their written composition skills in the English discipline. Similarly, none of the respondents' profiles, when considered individually, had a significant impact on their written composition in the English discipline.

The null hypothesis that there is no significant relationship between socio-demographic profiles and written composition in the English discipline among TRAC faculty members was accepted in this study. There was insufficient evidence to confirm the existence of a significant relationship between the respondents' socio-demographic profiles and their written performance in the English discipline.

\section{Conclusions and Recommendations}

Regarding the expressive, transactional, and poetic functions, the faculty members at Tawi-Tawi Regional Agricultural College showed a very high level of communicative reading comprehension competency for Britton's three primary language functions. The respondents gave a mean score of 78.98 out of a possible 100, with a standard deviation of 5.868, indicating moderate or good competency. Both conversational ability and sentence analysis were moderately adequate (2.46). Furthermore, it was determined that they are not avid readers, especially of English books. The researchers assessed faculty members from Tawi-Tawi Regional Agricultural College for communicative reading comprehension in Britton's three primary language functions (transactional, expressive, and poetic). The findings revealed that the respondents' gender had no bearing on their communication competency level. There were also no significant differences between male and female faculty members when they were classified as such. Additionally, no significant relationship was found between socio-demographic profiles and teaching performance in the English discipline.

Only the transactional and poetic functions were found to be good predictors of written composition discourse performance. Individually, none of the respondents' profiles had a significant impact on their written English discourse.

The researchers recommend further relevant research involving a wider range of educational parameters to determine further impacts of communicative reading comprehension competency on written composition discourse in one of 
the region's higher educational institutions. The study found that some institutions predominantly the reading comprehension/competency, good written composition skills, and productive academic performances.

\section{References}

Ababneh, S. (2020). Jordanian EFL students' use of English color terms in collocations. International Journal of Education and Practice, 8(4), 774-783. https://doi.org/10.18488/journal.61.2020.84.774.783.

Ahamad, J. K. (2002). Michael halliday's seven functions of language. Unpublished Dissertation, Mindanao Advanced Educational Project (MAEP) Scholarship, Ateneo de Zamboanga University, Zamboanga City.

Bachman, D. (1992). The limits on leadership in China. Asian Survey, 32(11), 1046-1062. https://doi.org/10.2307/2645270

Barman, A. K. (2020). English language teaching at secondary level in Bangladesh: An unsuccessful story. American Journal of Education and Learning, 5(1), 112-122. https://doi.org/10.20448/804.5.1.112.122

Britton, J. (1970). Language and learning. London: Allen Lane, The Penguin Press.

Brown, A. L., \& Campione, J. C. (1994). Guided discovery in a community of learners: The MIT Press.

Brown, P., Levinson, S. C., \& Levinson, S. C. (1987). Politeness: Some universals in language usage (Vol. 4): Cambridge University Press. https://doi.org/10.1017/CBO9780511813085

Brunner, J. (1970). From communication to language- a psychological perspective, cognitive english study. London: Edward Arnold.

Demirel, H., \& İşisağ, K. (2019). Cross-cultural transference in translation: Translator preferences in translating cultural elements from Turkish to English in Madonna in a Fur Coat By Sabahattin Ali. International Journal of Educational Technology and Learning, 5(1), 1-8. https://doi.org/https://doi.org/10.20448/2003.51.1.8

Garvey, C. (1977). Play with language and speech. In Child discourse (pp. 27-47): Academic Press. https://doi.org/10.1016/B978-0-12-241950-8.50008-3

Ge, S. (2021). Application of translation workshop to college English translation teaching. International Journal of Emerging Trends in Social Sciences, 10(1), 34-40. https://doi.org/https://doi.org/10.20448/2001.101.34.40

Kouiri, K. E., Agouram, J., \& Kadouri, A. (2021). Ownership structure and performance of companies: Exploratory study via a systematic review of the literature. International Journal of Social Sciences Perspectives, 8(1), 17-24. https://doi.org/10.33094/7.2017.2021.81.17.24

Norton, J. D. (1993). General covariance and the foundations of general relativity: Eight decades of dispute. Reports on Progress in Physics, 56(7), 791-858. https://doi.org/10.1088/0034-4885/56/7/001

Personske, C. R. (1987). Language art instruction and beginning teachers: A practical guide Journal in English Reading Comprehension, 9, 12-13.

Rahman, M. Z., Sony, M., Hossen Rubel, M. S., Alam, M., \& Liza, R. A. (2020). Steps toward smooth graduation of Bangladesh from least development countries. Journal of Contemporary Research in Social Sciences, 2(3), 57-67. https://doi.org/10.33094/26410249.2020.23.57.67

Yunus, M. M., Umiera, H., Makhtar, R., Norman, H., \& Hashim, H. (2020). The voyage of ESL Learners 'English language learning in the Era of post-colonialism: A thematic analysis. Humanities and Social Sciences Letters, 8(2), 224-229. https://doi.org/10.18488/journal.73.2020.82.224.229

\section{Copyrights}

Copyright for this article is retained by the author(s), with first publication rights granted to the journal.

This is an open-access article distributed under the terms and conditions of the Creative Commons Attribution license (http://creativecommons.org/licenses/by/4.0/). 